\title{
Postantique Soils as a Source of Land Use Information: A Case Study of an Ancient Greek Agricultural Area on the Northern Black Sea Coast
}

\author{
Fedor Lisetskii $\mathbb{C}^{1},{ }^{1}$ Vladimir Stolba $\mathbb{D}^{\mathbb{D}},{ }^{2}$ Aleksandra Golyeva, ${ }^{3}$ Olga Marinina, ${ }^{1}$ \\ and Arseniy Poletaev ${ }^{4}$ \\ ${ }^{1}$ Belgorod State National Research University, Federal-Regional Centre of Aerospace and Surface Monitoring of the Objects \\ and Natural Resources, Belgorod, Russia \\ ${ }^{2}$ Berlin-Brandenburg Academy of Sciences and Humanities, Berlin, Germany \\ ${ }^{3}$ Institute of Geography RAS, Moscow, Russia \\ ${ }^{4}$ Belgorod State National Research University, Institute of Earth Sciences, Belgorod, Russia
}

Correspondence should be addressed to Fedor Lisetskii; liset@bsu.edu.ru

Received 21 August 2019; Accepted 1 October 2019; Published 29 January 2020

Academic Editor: Davey Jones

Copyright () 2020 Fedor Lisetskii et al. This is an open access article distributed under the Creative Commons Attribution License, which permits unrestricted use, distribution, and reproduction in any medium, provided the original work is properly cited.

\begin{abstract}
As an effect of intensive agricultural development of the steppes of the northern Black Sea coast, the finds of postantique agricultural landscapes that preserve relic elements of ancient land-use infrastructure are extremely rare. To these belongs the uniquely preserved ancient Greek land division system on the Tarkhankut Peninsula (north-western Crimea), which was studied using the methods of soil science and biomorphic analysis. This paper explores ancient land-use practices in order to reconstruct the original parameters of the land division system, as well as agricultural techniques employed. For postantique agricultural landscapes, an integrated geoarchaeological approach that includes GIS and remote sensing methodologies, in-field study of microrelief and soil registrograms, pedochronological dating technique, and physicochemical, geochemical, and biomorphic soil analyses has been developed and tested. The soil-geomorphological reconstruction shows that the Hellenistic land division system included a 4.5-4.9 m wide strip of land bordered by a 4.1-4.7 $\mathrm{m}$ wide (at the base) and c. $0.2 \mathrm{~m}$ high wall and a c. $2 \mathrm{~m}$ wide and over $15 \mathrm{~cm}$ deep trench, which controlled surface runoff and erosion. Ancient agricultural practices of slope farming resembled the modern ones. Surface runoff and soil erosion were controlled by dividing the catchment area into narrow plots, the borders of which on arable land were marked by simple earthen structures (low walls with shallow trenches). The biomorphic analysis of soil sampled atop these structures indicates that in ancient times, these earthen walls were not cultivated. The study of conservative properties preserved in pedomemory of postagrogenic soils provided valuable evidence of agricultural techniques used in the palaeogeographic conditions of the $4^{\text {th }}$ and $3^{\text {rd }}$ centuries BC.
\end{abstract}

\section{Introduction}

Geoarchaeology as an integrative approach draws on a range of disciplines, including pedoarchaeology or archaeological soil science (archaeopedology) [1-3]. This synthesis of soil science and archaeology valuably enriches both branches of knowledge. The integration of palaeopedology and geoarchaeology not only allows for reconstructing the paleoenvironmental conditions in the Holocene [4-6] but also complements the study of soils developed on archaeologically datable surfaces [7], as well as the study of ancient landscapes (agricultural, residential, etc.) [8-10].

The geoarchaeological and, in particular, pedoarchaeological studies at ancient sites are decently present in the publications of the last few decades [11-13] and others, while the studies on ancient agrolandscapes and their soils are significantly fewer in number $[8,14-21]$. This is partially due to the fact that the ancient land plots and their earthen 
division walls are archaeologically mute objects, so that the eventual studies would usually lack the chronological reference points.

The studies by Frontinus, Urbicus, Hyginus, and other ancient writers preserved in the collection Corpus agrimensorum Romanorum inform us about Roman practices of land surveying and management [22-24]. However, with regard to the earlier Greek land management in the steppe zone of the northern Black Sea coast, our knowledge is much more limited, being based primarily on indirect evidence.

The modern remote-sensing techniques and the access to the satellite imagery of different seasons and resolution have significantly advanced the studies of ancient land use. After many centuries of agricultural activity, the traces of ancient land division systems, including those established on the northern Black Sea coast in the course of the Greek colonization, are not obliterated completely and can still be detected both on the satellite images and in the terrain. Boundary lines made of earth or stone marked the limits of ancient land plots, disturbing the topographic monotony of the steppe. The changes that ancient roads made in microrelief make them also well identifiable in postagrogenic landscapes [25].

Unlike other areas of the northern Black Sea region, western Crimea boasts an exceptionally well-preserved classical agricultural landscape, particularly on the Herakleian Peninsula around the ancient city of Chersonesos [26-34] and in parts of the Tarkhankut Peninsula where large areas still untouched by modern ploughing show the traces of ancient land use and management $[9,27,29,32,35-38]$. The traces of ancient land division have also been revealed in eastern Crimea, in the rural territory of the European Bosporos [39, 40].

On the Tarkhankut Peninsula, the traces of an extensive orthogonal land division system are discernable on archival aerial photographs where they appear as numerous parallel and perpendicular dark lines that delimit the plots measuring $420 \times 250-255 \mathrm{~m}$ (c. 10.5-10.70 ha) [41]. While Shcheglov [26, 35] ascribes these traces to the Hellenistic period, their chronology still needs to be ascertained.

While soils in general are an important source on the changes in the natural environment in the Holocene, soils that have experienced long-term agricultural loads preserve the record of these activities in their physicochemical and biogeochemical properties (or pedomemory), shedding light on the mechanisms of agrogenic soil evolution [42, 43]. The framing of the concept of soil memory and the perception of soils and soil cover as specific carriers of information about the evolution and interaction of the biosphere, geosphere, and human society signify an important milestone in the development of pedology [44]. Soil record or soil proxiindicators are the result of local interaction of soil-formation factors in time. Formed in situ, soil record possesses a high spatial resolution in each point of the earth surface [45].

It has been demonstrated that both natural and anthropogenic impacts under traditional farming leave an imprint in soil fertility parameters [8, 46, 47]. Ancient division walls and ditches with their own soil covering, as elements of a land division system, also are important relics of agricultural landscapes. Less transformed than the soils inside the plots, the soils on catenas of such division walls are particularly informative, containing the information about the time of their creation, as well as on the ancient agricultural practices.

The biomorphs of specific plant species, deposited in the soil, also prove an important source for reconstructing the changes in vegetation cover and soil evolution [48]. Since the first employment of phytoliths in the studies of archaeological sites [49-52], a number of new methodological approaches have emerged that broaden the possibilities of biomorphic analysis [53-61], and others. The application of phytolith analysis in pedological studies has shown its efficiency for reconstructing soil evolution and deducing local time scales for landscape development $[52,62]$.

Taking a multidisciplinary approach and deploying a variety of pedoarchaeological methods, including the soilgenetic dating technique, as well as physicochemical, biogeochemical, and biomorphic analyses of fallow soils, this paper aims to (i) reconstruct the original parameters of the land division structures and their chronology, (ii) obtain new data on the ancient agrotechnologies, and (iii) reconstruct the western Crimea's conditions of land use at the turn of the $4^{\text {th }}$ and the $3^{\text {rd }}$ centuries BC.

\section{Methodology}

2.1. Study Area and Historical Context. Except for the Soviet times, the most intensive use of agricultural lands in northwestern Crimea is associated with the period from the second quarter of the $4^{\text {th }}$ century to the middle of the 2 nd century BC when this territory was under control of the ancient city of Tauric Chersonesos $[63,64]$. While this part of Crimea is best known for its orthogonal land division system, space images also reveal some traces of nonlinear division in the chora (rural territory) of the ancient Greek city of Kerkinitis, west of modern-day Yevpatoria. Since archaeological excavations in the area of Kerkinitis revealed no traces of land division, it has been assumed that the land near the city was parcelled by means of low earthern walls or shallow trenches that are now obliterated ([38], p. 34).

Over the last four decades, the studies of ancient landdivision systems based on the high-resolution satellite imagery mainly characterized their topology and the units of linear measure employed. Three main types of land division systems that were identified include (1) regular (orthogonal), (2) irregular, and (3) the so-called "long fields." The features that on the aerial photos are interpreted as the traces of land division do often coincide with the boundaries of modern fields but remain invisible in the terrain. Therefore, the studies of centuries-old fallow lands with agrogenic microrelief, which can be found only in a few agricultural areas actively used in ancient times, are particularly important. In the inner structure of land plots, including the orientation of its long axes that also defined the tillage direction, the geomorphological factor (length and steepness of the slopes, as well as their exposure) and soil conditions decisive for crop specialization played an important role. 
In the second half of the $4^{\text {th }}$ century through the early $3^{\text {rd }}$ century BC, the seaside plain in the western part of the Tarkhankut Peninsula was the most populated and developed area and formed part of the distant chora of Chersonesos. For this period, the fallow land management system similar to that of the $19^{\text {th }}$ century, which assumed 6 to 8 years of continuous tillage with subsequent abandonment or a 3-8year tillage followed by an idle period of $8-15$ years, has been suggested $[38,63,65]$. The traces of ancient land plots, as well as the finds of agricultural tools and charred seeds of different crops, present farming as the leading sector of the economy. Main cultivars in the chora of Chersonesos included wheat, barley, and vine, and in the early $3^{\text {rd }}$ century $\mathrm{BC}$, the cropping of winter cereals might have been practiced [66].

The palaeogeographic data available [10] indicate that at the turn of the $4^{\text {th }}$ and the $3^{\text {rd }}$ centuries BC, the climate in the area was more humid than at present. The modern-day climate of this dry-steppe coastal region is characterized by fairly low precipitation of $316 \mathrm{~mm}$ per year and an evaporation/precipitation index of 2.6. Favourable climate in the conditions of the rising solar activity, from the Greek minimum (c. $2350 \mathrm{BP}$ ) to the turn of the eras, contributed to the active reproduction of steppe soils [67]. Natural and climatic conditions in the late $4^{\text {th }}$ and early $3^{\text {rd }}$ centuries BC were approximately the same as in the last third of the $19^{\text {th }}$ century through the 1930s, when the cultivation of barley and winter cropping of wheat dominated in agriculture [38].

The two typical varieties of land division around ancient settlements of north-western Crimea, i.e., the orthogonal (Tyumen 2) and "long field" types (Settlement S11-029 and Dzhangul) demonstrate the preferences in the choice of natural conditions for agriculture (Table 1).

The data in Table 1 demonstrate that at all three studied sites, there are conditions for the development of erosion, especially evident in the values of the relief function (LS) from the watershed to the first division wall on the slope. These values, which were calculated according to [68], show that the slopes of the ravine on which the settlement S11-029 was situated had the highest risk of erosion. The fact that this site also features the best preserved ancient agrolandscape explains the decision to study it in detail.

Land plot S11-029 with well-preserved division walls is located $5.25 \mathrm{~km} \mathrm{SE}$ of the settlement of Karadzha $\left(4^{\text {th }} \mathrm{c}\right.$. BC- $1^{\text {st }}$ c. AD) (Figure 1). It also formed part of the distant chora of Chersonesos, but, unlike Karadzha, was short-lived $\left(4^{\text {th }}\right.$-early $3^{\text {rd }}$ c. BC). Its water catchment area includes a gentle slope to the altitude of 41-88 $\mathrm{m}$ a.s.l. delimited on the west by the ravine's left tributary (Figure 1(c)).

According to the 1874-1929 data of the Tarkhankut Lighthouse meteorological station situated $5 \mathrm{~km}$ away from Site S11-029, the annual precipitation in this area amounted to $292 \mathrm{~mm}$, with the summer and autumn rainfall making $57 \%$ of the total. Over the 53 years of observations, the highest daily precipitation ( 48 to $61 \mathrm{~mm}$ ) is associated with summer rains. Thus, the conditions for soil erosion and the formation of ravines are still there, but in antiquity, these processes could have been more acute due to the agricultural development of the slopes. The climate of the $4^{\text {th }}$ century BC was more humid, although at the turn of the $4^{\text {th }}$ and the $3^{\text {rd }}$ centuries, it began to change towards more arid conditions $[69,70]$.

The land plot occupies the left slope of the ravine, facing north and northwest. Roughly square in plan, it measures $258 \times 286 \mathrm{~m}$, occupying an area of $7.37 \mathrm{ha}$. Its entire area is divided into 11 parcels. The direction of ploughing followed that of the division walls, i.e., west to east. The soil is represented by the loamy calcareous Chernozem, which has the following profile: Ad: $0-8, \mathrm{~A}: 8-21$; AB: $21-33 ; \mathrm{B}: 33-54 \mathrm{~cm}$. From the depth of $58-63 \mathrm{~cm}$, the particles of white Sarmatian limestone emerge in the profile. According to the GPR survey, the limestone bedrock is situated at the depth of $1.7 \mathrm{~m}$. The fact that on its west side the land plot is delimited by a gulley and on its east side, limestone comes close to the surface prevented the Soviet-time agricultural activity in this area. Thus, after a short period of development in ancient times, it remained in the fallow regime with the varying intensity of pasture load.

The vegetation of the fallow land (Figure 1(a), S2) is represented by herbs and grasses with the prevalence of feather grass (Stipa capillata, Poa bulbosa, Festuca valesiaca, with the participation of Artemisia taurica, Plantago lanceolata, and Phlomis tuberosa). At the site, within an area of $1 \mathrm{~m}^{2}, 12$ species of higher plants were identified with a plant cover of $95 \%$ (May). The territory is now used for moderate grazing of sheep. The presence among the grasses of two types of feather grass (Stipa capillata and Stipa lessingiana) indicates a low degree of pasture digression [71].

In the steppe zone, moisture is a limiting factor for phytoproductivity. Accordingly, the tops of the division walls as their less-humidified parts are covered by more xerophilous vegetation (Artemisia taurica Willd.), as compared to that in the depressions south of their bases (Figure 2(a)).

Current microlandscape differences of the studied objects: the fairly low division walls are exposed to denudation; their soil is drier, and the vegetation on their top is more xerophilic (sagebrush which is absent between the walls). Although shielded by the walls from the runoff, the soils within the plot receive additional moisture along the division walls, while dense plant cover intercepts sediments carried by water down the slope.

2.2. Soil Sampling Techniques. The geoarchaeological studies of fallow lands, combined with the remote sensing techniques, facilitated the identification of postantique agrolandscapes. Using GIS, the traces of the ancient land division system identified on satellite images were superimposed on topographic maps. In the terrain, the geodetic survey and soil registrograms with detailed fixation of horizons allowed to capture in the c. $20 \mathrm{~m}$ long cross-sections all relevant soil changes, comparing them with reference sections outside the plot.

The microtopography of the land division system was studied using total station Topcon GM-105. The relief function (LS) was calculated using Morgan's formula [68]:

$$
\mathrm{LS}=\frac{\sqrt{L}}{100} \cdot\left(1.38+0.965 \cdot S+0.138 \cdot S^{2}\right)
$$


TABLE 1: Characteristics of relief outside the land plots and the basic parameters of the division system.

\begin{tabular}{lccccc}
\hline \multirow{2}{*}{ Site } & \multicolumn{2}{c}{ Relief before the first boundary } & \multicolumn{2}{c}{ Land division system } \\
& Slope length $(L), \mathrm{m}$ & Slope gradient $(S), \%$ & LS & E & Plot width, m \\
\hline Settl. S11-029 & 1710 & 2.69 & 2.06 & 23.85 & 161.16 \\
Dzhangul & 1210 & 1.39 & 1.04 & $20-24$ \\
Tyumen 2 & 146 & 0.7 & 0.26 & 35.26 & 50 \\
\hline
\end{tabular}

E: deviation of the division wall axes from $N$ (azimuth).
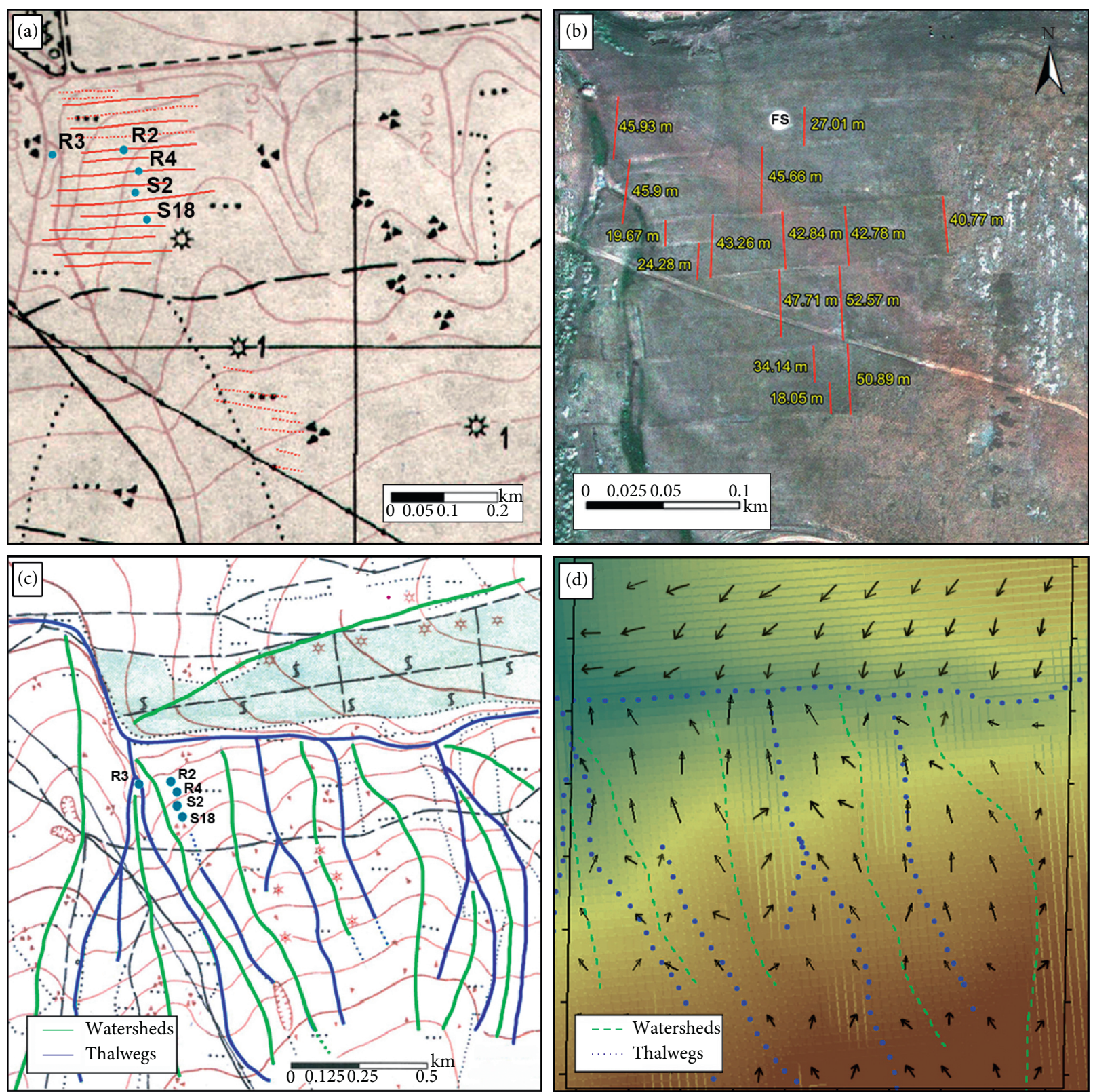

Figure 1: Postagrogenic landscape in the area of settlement S11-029 (last quarter of the $4^{\text {th }}$ to first third of the $3^{\text {rd }}$ c. BC). (a) Division walls detected on satellite images superimposed on a topographic map (red lines: earthen walls; blue dots: soil sections). (b) Satellite image of the same area (FS: ancient farmhouse). (c) Water catchment area of the site. (d) Digital elevation model of the site area with water flow lines.

where $L$ is the slope length $(\mathrm{m})$ and $S$ is the slope gradient (\%).

Within the ancient land plot, transverse cross sections through walls R2, R3, and R4, as well as between the walls
(Sections S2 and S18), were made (Figures 1(a) and 1(c)). In addition, $11 \mathrm{~km} \mathrm{NE}$ of the settlement S11-029, in a similar land division system which is now in the fallow regime but has been recently cultivated, we studied soils on the top of a 

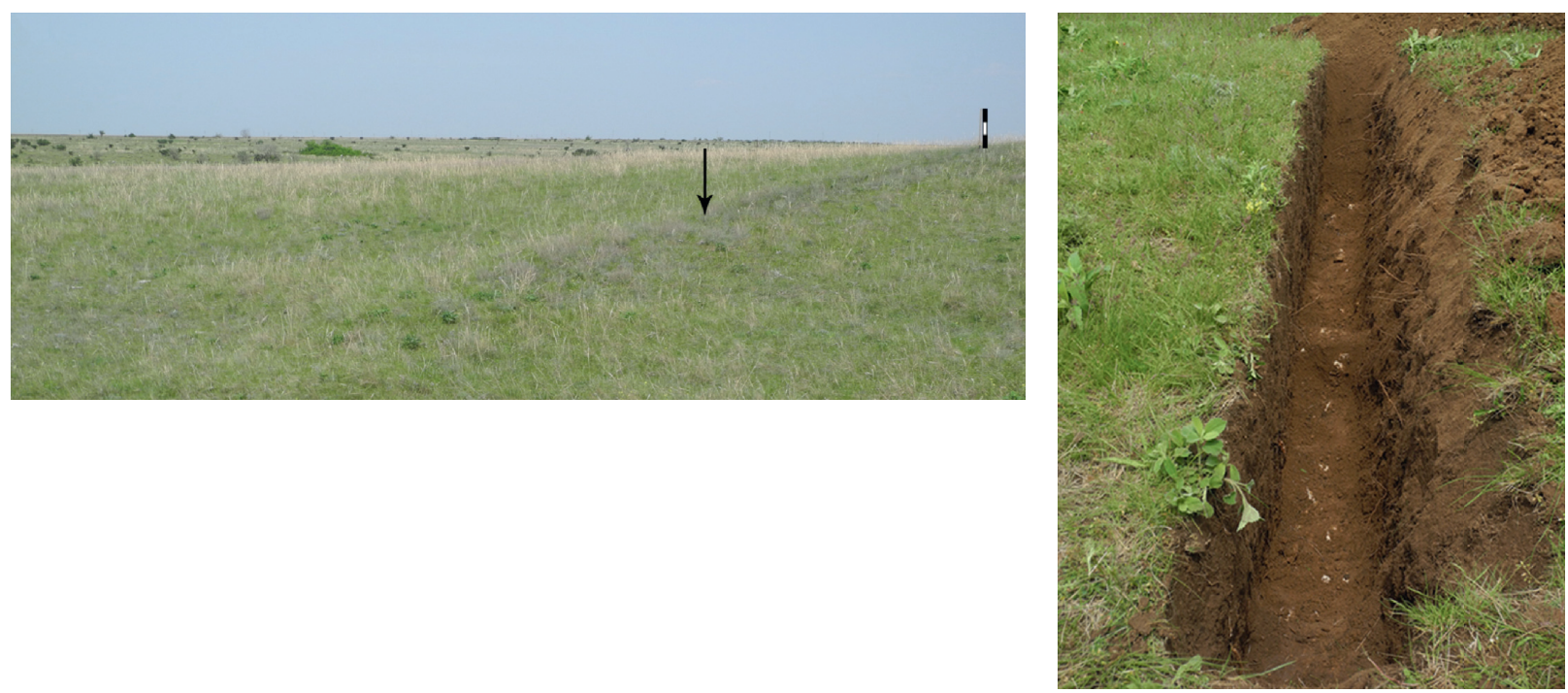

(a)

(b)

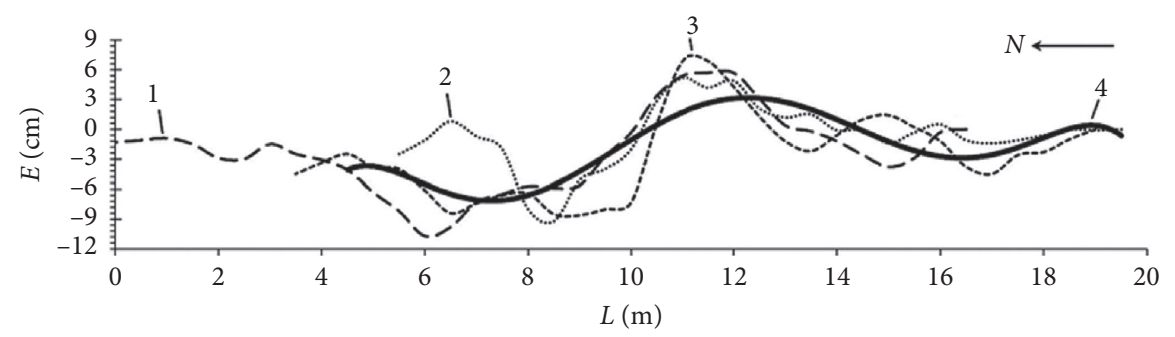

(c)

FIGURE 2: (a) Western part of wall R2. (b) Section through wall R2. (c) Combination of geodesic profiles of walls R2 (1), R3 (2), R4 (3), and a polynomial trend (4). E: relative excess along the length $(L)$ of the trench. The location of the walls is shown in $1(\mathrm{a})$ and $1(\mathrm{c})$.

division wall (R5) and inside the plot (S5). At site S11-029, samples for a biomorphic analysis were taken along the soil profiles at the top of the wall (R2 (F3)) and inside the plot (S2 (F2)). The thickness of the soil layer $(34 \mathrm{~cm})$ in which samples for biomorphic analysis were taken, corresponds to that of the humus horizon $(\mathrm{A}+\mathrm{AB}=33 \mathrm{~cm})$ attested near the ancient farmhouse inside the land plot (FS, Figure 1(b)).

To characterize the morphometric parameters of the division walls, Lisetskii's data, containing the results of his study of relic geomorphological forms of ancient agricultural landscapes on fallow lands of the Crimean Peninsula, were used [72]. The parameters of the microrelief and soil cover within the ancient land division structures were assembled in a special database [72]. Soil sampling on the fallow land was conducted in horizon $A$ in the $0-15$ (17) cm layers. The samples from each studied site consisted of three subsamples. The geochemical characteristics of the parent rock, which was sampled at the depth of $60-70 \mathrm{~cm}$, were required to calculate the coefficient of the microelement accumulation capability.

The pedochronological method of dating archaeological sites is based on mathematical modelling of the dependence of the development of irreversible soil properties on time, in particular on the chronofunction of the humus horizon thickness $(A+A B)$ change in time [73]. The pedochronological method of dating of newly formed soils [7] was supplemented by soil chemical analyses.

2.3. Soil Laboratory Analysis. The main analytical procedures were performed according to standard methods [74] in the Chemical-Analytical Complex of the Institute of Physical, Chemical and Biological Problems in Soil Science, Russian Academy of Sciences, Pushchino. Chemical analyses of soils included the following standard procedures: the $C_{\text {org }}$ content by Tyurin's method (by oxidation of the organic substance with a solution $\mathrm{K}_{2} \mathrm{Cr}_{2} \mathrm{O}_{7}$ in sulphuric acid); $\mathrm{CO}_{2}$ in carbonates by acidometry; $\mathrm{pH}\left(\mathrm{H}_{2} \mathrm{O}\right)$ by potentiometric method ( $\mathrm{pH}$ meter Sartorius Basic Meter PB-11); the available $\mathrm{P}_{2} \mathrm{O}_{5}\left(\mathrm{mg} \cdot \mathrm{kg}^{-1}\right)$ by Machigin's method (spectrophotometer UNICO-1200), and $\mathrm{K}_{2} \mathrm{O}$ on a fiery photometer. Total nitrogen (N) was estimated by Kjeldahl's procedure. The group analysis of humus (humic acid (HA) and fulvic acid (FA)) was carried out using Tyurin's method modified by Ponomareva and Plotnikova [74]. The determination of cation exchange capacity (CEC) in calcareous soils was performed using EDTA- $\mathrm{Na}_{2}$. Concentration of 16 metals and their oxides (8 macroelements and 8 trace elements) within the soils was determined by the technique of measuring the metal's mass fraction and the oxides in powder samples using XRF (Spectroscan Max-GV). Soil colours were described using the Munsell system [75]. 
Biogeochemical indicators for fallow lands of the steppe zone were established in [76] and are adopted in this study. The most informative indicators for soils were selected using the threshold value of the coefficient of variation $(V \geq 10 \%)$. The coefficient of eluvium $\left(K_{\mathrm{e}}\right)$ is calculated using the modified formula proposed by $\mathrm{Liu}$ et al. [77]: $K_{\mathrm{e}}=\mathrm{Al}_{2} \mathrm{O}_{3}$ / $\left(\mathrm{MnO}+\mathrm{CaO}+\mathrm{K}_{2} \mathrm{O}+\mathrm{MgO}+\mathrm{Na}_{2} \mathrm{O}\right)$. A useful index of potential soil fertility (FI) is the ratio of the base cation elements, calcium and magnesium, and total phosphorus to silicon, i.e., $\mathrm{FI}=\left(\mathrm{CaO}+\mathrm{MgO}+10 \cdot \mathrm{P}_{2} \mathrm{O}_{5}\right) / \mathrm{SiO}_{2}$ [78]. Mobility factor was assessed using the formula: $K_{\mathrm{m}}=\left(\mathrm{Na}_{2} \mathrm{O}+\mathrm{K}_{2} \mathrm{O}+\right.$ $\mathrm{MgO}+\mathrm{Zn}) / \mathrm{SiO}_{2}$. Shaw [79] proposed the coefficient of accumulation of trace elements to calculate the arithmetic mean of the relationship of trace elements in the soil (S) to the parent rock $(\mathrm{P})$. We used the modification of this coefficient $\left(K_{\mathrm{S}}\right)$ as a geometric mean value $\mathrm{S} / \mathrm{P}$ for the trace elements group ( $\mathrm{Ni}, \mathrm{Zn}, \mathrm{Mn}, \mathrm{Pb}, \mathrm{Cu}, \mathrm{Co}, \mathrm{Si}, \mathrm{P}$, and $\mathrm{K}$ ). The "coefficient of leaching" $\beta$, which is calculated as the ratio $\beta=b$ of soil (in horizon $n) / b$ of rock, where $b=\left(\mathrm{K}_{2} \mathrm{O}+\mathrm{Na}_{2} \mathrm{O}\right) / \mathrm{Al}_{2} \mathrm{O}_{3}$ [80], was used to assess the extent and duration of agrogenic soil transformation. Integrated assessment of soil quality (SQ) takes into account the content (\%) of 10 elements ( $\mathrm{Ca}, \mathrm{K}, \mathrm{Si}, \mathrm{Mg}, \mathrm{Mn}, \mathrm{Al}, \mathrm{Fe}, \mathrm{Ni}, \mathrm{Cu}$, and $\mathrm{Zn}$ ), using the formula for the geometric mean.

For biomorphic analysis, the standard sample treatment technique was used [54, 62]. Soil samples of $40 \mathrm{~g}$ selected for this purpose were treated with a $30 \%$ solution of $\mathrm{H}_{2} \mathrm{O}_{2}$ and heavy liquid (an aqueous solution of $\mathrm{CdI}_{2}$ and $\mathrm{KI}_{2}$ with a specific gravity of 2.3) and then centrifuged for 10 minutes. The floating biomorphs were washed with distilled water and centrifuged again. The remaining fraction was diluted with glycerol, and $1 \mathrm{~mm}^{3}$ of obtained sample was examined with an optical microscope at a magnification of 250-350x.

\section{Results and Discussion}

3.1. Geomorphological and Hydrological Conditions of Land Use. Land plot S11-029 is situated on the left side of a noname ravine, occupying its undulating slope exposed to $\mathrm{NNW}$. It is $1,945 \mathrm{~m}$ long (from the watershed to the ravine's thalweg) and $800 \mathrm{~m}$ wide (from the outcrops of Neogenic limestone to a small gully that empties into the ravine). Earthen division walls occupy the lower part of the slope and follow the direction of the ravine. The soil is Rendzic leptosol (skeletic), quite shallow in the upper part of the slope where it lies on the eluvium or limestone bedrock, but gains in thickness towards its bottom where the plant roots reach the depth of $63-70 \mathrm{~cm}$.

The orientation of earthen walls perpendicular to the main gradient of the slope allowed for controlling the surface runoff. In addition to the main walls that divided the plot into c. $46 \mathrm{~m}$-wide fields, a number of internal walls dividing these fields into two narrower parcels of roughly equal size have been identified (Table 2). The average values of the actually measured widths of narrow fields amounted to 22-23.5 $\mathrm{m}$ what roughly corresponds to a half width of large fields of $46 \mathrm{~m}$. The data presented in Table 2 show that the differences between these two parameters are statistically insignificant $(P<0.5)$. The fact that at the depth of $56-63 \mathrm{~cm}$
TABLE 2: Widths (m) of fields at land plot S11-029.

\begin{tabular}{lccc}
\hline No. & Narrow $(L 1)$ & Wide $(L 2)$ & $L 2 / 2$ \\
\hline 1 & 18.05 & - & - \\
2 & 19.67 & - & - \\
3 & 24.28 & - & - \\
4 & 27.01 & - & - \\
5 & 20.39 & 40.77 & 20.39 \\
6 & 21.39 & 42.78 & 21.39 \\
7 & 21.42 & 42.84 & 21.42 \\
8 & 21.63 & 43.26 & 21.63 \\
9 & 22.83 & 45.66 & 22.83 \\
10 & 22.95 & 45.90 & 22.95 \\
11 & 22.97 & 45.93 & 22.97 \\
12 & 23.86 & 47.71 & 23.86 \\
13 & 25.45 & 50.89 & 25.45 \\
14 & 26.29 & 52.57 & 26.29 \\
Average & $22.73 \pm 0.68$ & $45.83 \pm 1.18$ & $22.92 \pm 0.59$ \\
\hline
\end{tabular}

a test pit dug under one of the main walls revealed limestone boulders (Figure 2(b)) suggests that prior to the construction, the axes of the future division system could have been marked with stones.

In the division systems of orthogonal and irregular plan, the intersecting walls assured the absorption of water within the field parcels. In the case of land plot S11-029, no signs of such transverse barriers within the long fields have been identified. This conditioned the washoff processes and the distribution of rainfall runoff along the boundary walls and impacted the soil formation processes after the 3rd century $\mathrm{BC}$ when the fields were abandoned.

In conditions of slope farming, the arrangement of fields along the hypsographic lines made it possible to perform ploughing along the course of the ravine. Such arrangement is also effective in terms of runoff and washoff control and, as we see, was practiced in ancient times. In conditions of southern dry steppes, the interception of rainfall runoff facilitated "dry" amelioration without irrigation. In agroclimatic terms, the NW-SE and NE-SW orientation of seeding rows is most effective, as providing the maximum yield [10].

In difficult terrain conditions of plot S11-029 (plot size: $234 \times 286 \mathrm{~m}$; slope gradient in its lower part: $2.45^{\circ}(4.27 \%)$, with longitudinal and transverse inclinations), ancient farmers failed to control runoff effectively within narrow fields, despite the fact that the direction of internal walls was closely following the orientation of hypsographic lines. This is evidenced by the well-preserved part of the wall intersected by a gully that has developed over several decades of ancient farming (Figure 1(b)). This gully traverses the western part of the land plot and has a length of 1,645 m.

Even though some uncertainties as to ancient climate still exist, there is no doubt that soil erosion must have been active even in semiarid conditions. This is also suggested by the modern-day regional rainfall pattern in the growing season of cultivated plants. According to the 53-year record of observations, the monthly precipitation maxima, mainly due to erosion-dangerous shower rains, are attested in the summer: 120 and $117 \mathrm{~mm}$ in June and July, respectively, while the highest daily precipitation $(61 \mathrm{~mm})$ is recorded in August. 
3.2. Land Division Structures in Postantique Landscapes. Although erosion and accumulation processes become apparent at a larger-scale level, the fact that erosion is observed on microslopes and on the tops of the division walls, while sediments tend to be accumulated in the nearby schallow trenches, makes it possible to term this geomorphological compound an erosional microcatena. The resulting hypsographical trend for three earthen walls examined in plot S11-029 (Figure 2(c)) reveals the following sequence of modern relief microforms towards the slope's base: (1) a shallow, about $2 \mathrm{~m}$-wide trench; (2) a 9-12 cm-high wall with a longer lower-side slope; (3) a deep depression just behind the wall.

The neighbouring walls R2 and R4 belong to the same relief mesoform, which distinguishes them from R3, which is the continuation of wall R2 cut off by the gully. It is noticeably shorter and lower than other walls, and its profile, as well as that of its adjoining trench, is better pronounced, the gradient of its lower-side slope being 1.2-1.5 times higher (Figure 2(c)). The relief conditions, however, make it clear that wall R3 could not have been created in the modern period and is of much earlier age, corresponding to the time of the initial land division. Other studied walls (R2 and R4) and their on-slope analogues could have been renewed in the process of site agricultural exploitation.

The impact of the syngenetic processes of denudation and pedogenesis are well reflected in the soil cover registrograms, obtained in soil sections made through the division walls. The measurements of surface microrelief at $\mathrm{R} 2$ revealed that the current total width of the entire structure profile (wall and trench) amounts to $9.6 \mathrm{~m}$, the wall itself being $3.7 \mathrm{~m}$ wide (at the base) and $16-17 \mathrm{~cm}$ high. The reconstruction of the original parameters of earthen walls using the soil-morphological method has shown that the width of anthropogenic ground disturbances (wall and trench) amounted to $4.5-4.9 \mathrm{~m}$; the width of the wall (at the base) was $4.1-4.7 \mathrm{~m}$ and its height did not exceed $0.20 \mathrm{~m}$.

The registrograms reflecting the morphological heterogeneity of soils in sections laid through the division walls make it possible to determine the peculiarities of tillage inside the land plots, which is virtually impossible to establish by other methods. It seems that a Greek bow ard with horizontal runner widespread throughout the ancient world was used for cultivation. The soil registrogram demonstrates that the depth of the humus horizon on top of the walls amounted in average to $51 \mathrm{~cm}$ (varying from 45 to $57 \mathrm{~cm}$ ), while outside the walls to only $41 \mathrm{~cm}$ (varying from 38 to $44 \mathrm{~cm}$ ). Taking into account the extreme values, the difference in the humus horizon thickness at these two points reached $19 \mathrm{~cm}$. For the construction of division walls, humus material from a c. $4.5 \mathrm{~m}$ wide strip on the wall's southern side has been used. This operation resulted in a shallow trench in front of the wall (modern depth: $15 \mathrm{~cm}$ ) which regulated rainfall runoff and prevented erosion. It is difficult to say whether this solution was deliberate, but from the standpoint of the modern practice of agriculture in dry areas, this practice of land management should be regarded as an example of a nature-based solution [81].

Over the years, the walls have lost their original shape, but their humus profile was continuously developing.
Although the land division systems, just as bulwarks and other earthen structures, are archaeologically mute objects, their chronology can be ascertained using the pedochronological dating technique [7]. The pedochronological dating, together with the surface finds of early Hellenistic pottery made in the area of the farmhouses, strongly suggest that settlement S11-029 and the land division system belong to the same period and ceased to exist in the first half of the $3^{\text {rd }}$ century BC (Figure 1(b), FS). Under the condition that individual layers are brought to an equilibrium density of $1.15 \mathrm{t} \mathrm{m}^{3}$, the total depth of the humus horizon $(\mathrm{A}+\mathrm{AB})$ inside the land plot amounted to $346 \mathrm{~mm}$, which, using the pedochronological method of dating [7], corresponds to an age of 2,240 years. The fact that a storage pit containing $4^{\text {th }}$ century BC pottery has been found under wall R3 indicates, however, that the division of land has taken place not simultaneously with the establishment of the settlements, but at some later point, in the last third of the $4^{\text {th }}$ century BC. Land use must have lasted no more than half a century, as around $270 \mathrm{BC}$, all rural settlements in north-western Crimea perish $[65,82,83]$. This area has not been cultivated ever since, and, based on the set of soil and genetic data (see Section 3.3.), it can safely be defined as postantique fallow land.

\subsection{Physicochemical and Biogeochemical Soil Indicators in} Postantique Landscapes. The data presented in Table 3 show significant differences in soil properties in samples taken atop the division walls and inside the fields. This is first of all reflected in a lower content of $C_{\text {org }}$ in soils from inside the fields, which is due to the dehumification caused by agricultural activities. At the same time, in horizon $A$, these soils show a better quality of humus (as reflected in the ratio $\mathrm{CH} / \mathrm{CF})$ and a high degree of its nitrogen enrichment $(\mathrm{C} /$ $\mathrm{N}=5-7$ ), whereas in the soils in the upper part of the walls, these values are medium and low. The soils inside the fields, just as virgin soils, have a lower total of exchangeable bases, as compared to soils on walls. Considering a single data sample, no statistical relationship between total and labile phosphorus in virgin soil and soils of the division walls could be established (Table 3). A positive relationship between these phosphate forms observed in fallow soils makes them a relatively independent group, especially if the data of horizon A are considered separately. No differences in the content of exchangeable potassium have been revealed.

It would be most correct to compare the objects that are located nearby, for example, R2 and S2, which are only $10 \mathrm{~m}$ apart. The soil of the postantique fallow land (S2) near division wall R2 is calcareous and medium loamy Chernozem that has the following morphological structure: $\mathrm{Ad}$ $(0-8 \mathrm{~cm}) ; \mathrm{A}(8-21 \mathrm{~cm}) ; \mathrm{AB}(31-33 \mathrm{~cm}) ; \mathrm{B}(33-65 \mathrm{~cm})$; $\mathrm{BC}_{\mathrm{Ca}}$. The upper $17 \mathrm{~cm}$ represent the restored postagrogenic horizon which is uniform in colour and structure but is 1.5 times more calcareous and contains 1.4 times more labile phosphorus than the underlying horizon. Also, it is poorer in humus (13\% relative) and in labile potassium (34\%) (Table 3 ). Hence, despite the long period of soil-fertility 
TABle 3: Chemical properties of soils atop the division walls (R2, R5), inside the fields (S2, S5, S18), and in virgin conditions (S15).

\begin{tabular}{|c|c|c|c|c|c|c|c|c|c|c|c|c|c|}
\hline \multirow{2}{*}{ No. } & \multirow{2}{*}{ Depth $(\mathrm{cm})$} & \multirow{2}{*}{ Munsell (dry) } & \multirow{2}{*}{$\mathrm{pH} \mathrm{H}_{2} \mathrm{O}$} & \multirow{2}{*}{$\mathrm{CaCO}_{3}$} & \multirow[t]{2}{*}{ Corg } & \multicolumn{3}{|c|}{$\begin{array}{l}\text { Cation exchange } \\
\text { capacity, cmol.kg }\end{array}$} & \multicolumn{2}{|c|}{ Available } & \multirow[t]{2}{*}{$P$ tot. } & \multirow{2}{*}{$\begin{array}{r}\mathrm{C} / \mathrm{N} \\
\% \\
\end{array}$} & \multirow[t]{2}{*}{$\mathrm{CH} / \mathrm{CF}$} \\
\hline & & & & & & $\mathrm{Ca}^{2+}$ & $\mathrm{Mg}^{2+}$ & $\mathrm{Na}^{+}$ & \multicolumn{2}{|c|}{$\mathrm{mg} \cdot \mathrm{kg}^{-1}$} & & & \\
\hline \multicolumn{14}{|c|}{ Rendzic leptosol (virgin) } \\
\hline \multirow{2}{*}{ S15 } & $0-24$ & 10YR $7 / 3$ & 8.3 & 59.5 & 1.97 & 10.2 & 2.2 & 0.8 & 11.7 & 458.4 & 0.24 & 9.4 & 0.6 \\
\hline & $24-32$ & 10YR 6/6 & 8.6 & 60.9 & 1.74 & 5.9 & 2.0 & 2.0 & 6.2 & 615.6 & 0.26 & 7.8 & 0.6 \\
\hline \multicolumn{14}{|c|}{ Soils on the top of division wall R2 } \\
\hline \multirow{4}{*}{$\mathrm{R} 2$} & $0-20.5$ & 10YR 6/3.5 & 8.5 & 31.0 & 2.61 & 17.0 & 1.4 & 0.6 & 14.0 & 423.6 & 0.16 & 12.9 & - \\
\hline & $20.5-51$ & 10YR $5 / 3.5$ & 8.6 & 27.0 & 2.23 & 16.5 & 1.7 & 0.6 & 6.6 & 299.1 & 0.15 & 12.5 & - \\
\hline & $30-33$ & 10YR 5/3.5 & 8.4 & 20.8 & 3.35 & 22.1 & 3.6 & 0.9 & 4.7 & 182.5 & 0.13 & 8.7 & 0.2 \\
\hline & $33-36$ & $10 \mathrm{YR} 5 / 4$ & 8.4 & 19.1 & 3.12 & 21.3 & 4.0 & 0.9 & 3.7 & 164.1 & 0.12 & 6.7 & 0.3 \\
\hline \multicolumn{14}{|c|}{ Soils on the top of division wall R5 } \\
\hline & $0-13$ & $10 Y R 5 / 3$ & 8.3 & 3.2 & 1.57 & 23.6 & 3.0 & 0.95 & 1.6 & 228.4 & 0.12 & 9.6 & 1.0 \\
\hline \multirow[t]{2}{*}{ R5 } & $13-33$ & 10YR 5/2.5 & 8.4 & 0.7 & 1.35 & 25.2 & 2.8 & 0.95 & 0.8 & 184.5 & 0.12 & 7.4 & 1.3 \\
\hline & $33-48$ & $10 \mathrm{YR} 5 / 4$ & 8.6 & 8.6 & 1.80 & 20.8 & 3.9 & 0.8 & 1.9 & 140.5 & 0.13 & 3.8 & 0.5 \\
\hline \multicolumn{14}{|c|}{ Soil inside the fields } \\
\hline & $0-17$ & $10 Y R 5 / 4$ & 8.1 & 22.6 & 1.25 & 16.9 & 1.5 & 0.5 & 9.2 & 233.9 & 0.16 & 4.7 & 4.6 \\
\hline \multirow[t]{2}{*}{ S2 } & $17-21$ & $10 Y R 5 / 3$ & 8.2 & 14.9 & 1.43 & 15.8 & 1.5 & 0.5 & 6.4 & 353.8 & 0.16 & 6.0 & 0.9 \\
\hline & $21-33$ & $10 \mathrm{YR} 5 / 3$ & 8.2 & 28.1 & 0.36 & 15.4 & 1.4 & 0.5 & 5.7 & 511.7 & 0.17 & 1.6 & 3.4 \\
\hline \multirow{2}{*}{ S18 } & $0-15$ & $10 Y R 5 / 3$ & 8.1 & 19.2 & 1.38 & 13.6 & 1.6 & 0.4 & 10.1 & 368.9 & 0.15 & 5.3 & 1.9 \\
\hline & $15-27$ & $10 \mathrm{YR} 5 / 3$ & 8.2 & 24.5 & 1.10 & 11.1 & 1.1 & 0.3 & 5.1 & 199.0 & 0.14 & 5.6 & 0.8 \\
\hline \multirow{2}{*}{ S5 } & $0-17$ & $10 Y R 5 / 3$ & 8.2 & 29.1 & 1.53 & 18.7 & 2.3 & 0.3 & 9.7 & 424.2 & 0.16 & 6.8 & 1.0 \\
\hline & $17-34$ & $10 \mathrm{YR} 5 / 3$ & 8.2 & 39.8 & 2.04 & 11.5 & 2.0 & 0.3 & 5.5 & 215.8 & 0.15 & 12.5 & 0.9 \\
\hline
\end{tabular}

regeneration, the effects of ploughing activities are not completely obliterated. A similar comparison of the newly formed soil and the underlying (buried) humus horizon at the division wall has shown the following fundamental difference from the fallow land: soil of the upper part of the profile is more fertile by all parameters; it is 2.1 times richer in phosphorus, 1.4 times in potassium, 1.2 times in humus, and about so much more calcareous. This suggests that in ancient times, division walls were not cultivated.

The soils of the study area are rich in calcium oxide, which is reflected in the increased concentration of $\mathrm{CO}_{2}$ carbonates (Table 3 ). In such conditions, when soil solutions have a medium-alkaline reaction $(\mathrm{pH}=8.1-8.6)$, chemical migration of elements is difficult. Soils with varying degrees of anthropogenic change differ most in the concentration of calcium and silicon oxides, as well as in trace elements such as $\mathrm{Co}, \mathrm{Ni}, \mathrm{Cu}, \mathrm{Zn}, \mathrm{Sr}, \mathrm{Pb}$, and $\mathrm{Cr}$ (Table 4). The most informative biogeochemical indicators selected from the initial data (Table 4) according to their variation coefficient value ( $\mathrm{V} \geq 10 \%$ ) show differences between the upper horizons of soil within the ancient fields and atop the division walls (Table 5).

The biogeochemical features of the upper horizon of fallow soils are primarily determined by chemical elements such as $\mathrm{Ca}, \mathrm{Na}, \mathrm{K}, \mathrm{Al}, \mathrm{Fe}, \mathrm{Mg}, \mathrm{Mn}$, and $\mathrm{Zn}$, as well as the contents of accumulated microelements, biophilic elements, and some heavy metals. It is reasonable to include the above elements in the formulas for the calculation of geochemical relationships and the coefficients using stable elements in the diagnostics of elementary soil-forming processes [76].

To compare soils inside the fields and atop wall R2, wall's soil that was sampled at the depth of $20-51 \mathrm{~cm}$ from the surface and has never experienced effects of agrogenic activity and erosion has been used as a reference point. According to the ratios $(\mathrm{CaO}+\mathrm{MgO}) / \mathrm{Al}_{2} \mathrm{O}_{3}$ and especially $\left(\mathrm{K}_{2} \mathrm{O}+\mathrm{Na}_{2} \mathrm{O}\right) / \mathrm{Al}_{2} \mathrm{O}_{3}$, the soil at such depth was less susceptible to chemical weathering than the overlying $0-20 \mathrm{~cm}$ horizon. A comparison by coefficient $K_{\mathrm{S}}$ shows that soil of horizon A $(0-20 \mathrm{~cm})$ in its relation to the layer of $20-51 \mathrm{~cm}$ is poorer in chemical elements $\left(K_{\mathrm{S}}\right.$ is 1.01$)$ than the old arable soils (upper horizon relative to the lower): $K_{\mathrm{S}}(\mathrm{S} 2): 1.03$ and $K_{\mathrm{S}}$ (S18): 1.08. This is a clear indication that erosion and the peculiarities of pedogenesis, due to xerophilic phytocenoses, had an impact on wall soil at this location.

It has been shown [74] that $3 \mathrm{~cm}$ thick layers immediately above and below the boundary between the lower part of the newly formed humus horizon and the upper part of the underlying humified material clearly differ in the contents of nitrogen and organic matter; they also differ in the qualitative composition of humus. A comparison of the newly formed soil $(0-21 \mathrm{~cm})$ and the buried humus-containing layer $(33-36 \mathrm{~cm}$ ) atop wall R2 (Table 3 ) shows their significant difference: horizon A of the wall is more fertile by all parameters than the buried soil. This fact also prompts the conclusion that in ancient times, division walls were not cultivated.

The differences between fallow lands of different age (S2, S18) and S5 are well reflected in the potential soil fertility index (FI) [78]. A comparison by this index shows a significant difference between wall R2 and wall R5, which, being cut off by the gully, retained the original properties of the upper horizon, i.e., was not renewed later. In both cases, the termination of the anthropogenic soil disturbance is best reflected in the calcium oxide content. The analysis of the values of coefficient $K$ s, which reflects the accumulation of nine chemical elements in relation to the parent rock, shows 
TABLE 4: Results of the gross analysis of soils atop the division walls (R2, R5), inside the fields (S2, S5, S18), and in virgin conditions (S15).

\begin{tabular}{|c|c|c|c|c|c|c|c|c|c|c|c|c|c|c|c|c|c|}
\hline \multirow{2}{*}{ No. } & \multirow{2}{*}{ Depth $(\mathrm{cm})$} & \multicolumn{8}{|c|}{ Macroelements (\%) } & \multicolumn{8}{|c|}{ Trace elements (ppm) } \\
\hline & & $\mathrm{CaO}$ & $\mathrm{Al}_{2} \mathrm{O}_{3}$ & $\mathrm{MnO}$ & $\mathrm{Fe}$ & $\mathrm{SiO}_{2}$ & $\mathrm{~K}_{2} \mathrm{O}$ & $\mathrm{MgO}$ & $\mathrm{Ta}_{2} \mathrm{O}$ & Co & $\mathrm{Ni}$ & $\mathrm{Cu}$ & $\mathrm{Zn}$ & $\mathrm{Sr}$ & $\mathrm{Pb}$ & $\mathrm{Cr}$ & As \\
\hline \multicolumn{18}{|c|}{ Rendzic leptosol (virgin) } \\
\hline \multirow{2}{*}{ S15 } & $0-24$ & 33.64 & 09 & 0.07 & 1.79 & 5.42 & 1.44 & 3.57 & 0 & 2.83 & 0.57 & 20.03 & 65.15 & 39 & 12.62 & 0.46 & 5.91 \\
\hline & $24-32$ & & 48 & 0.06 & 1.92 & & & & & & & 16.27 & & & & & 5.71 \\
\hline \multicolumn{18}{|c|}{ Soil atop wall R2 } \\
\hline \multirow{2}{*}{$\mathrm{R} 2$} & & 10.57 & 11.00 & 0.10 & 2.88 & 620 & 1.8 & 1.51 & 1.0 & 17. & 46 & 38.02 & 88.46 & & 20.69 & 2.53 & 7.42 \\
\hline & 20, & & 04 & 0.10 & 2.96 & $38 .($ & 18 & 13 & 1 & 17.72 & 48.04 & 41.46 & 82.29 & & 24.97 & 8 & 6.29 \\
\hline \multicolumn{18}{|c|}{ Soil atop wall R5 } \\
\hline \multirow{3}{*}{ R5 } & 0.12 & 3 & & 10 & .27 & 2 & & 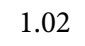 & 0.69 & 5 & 0 & 47.20 & 8 & & 28.94 & 8 & 6.94 \\
\hline & 13 & & 0 & 0.11 & 3 & 50 & & & & 7 & & 50.27 & & & 5 & 27 & 6.87 \\
\hline & $53-40$ & 3.0 & & 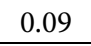 & & & & & & & & 3.24 & & & & & 5.93 \\
\hline \multicolumn{18}{|c|}{ Soils inside the fields } \\
\hline \multirow{3}{*}{ S2 } & 17 & 13.54 & .96 & 0.08 & 2.66 & 5.16 & 1.71 & 2.05 & 1.60 & 1.93 & 45.00 & 36.67 & 77.54 & & 17.22 & 9.98 & 7.48 \\
\hline & 1701 & 13.75 & 10.78 & 0.09 & 2.77 & 44.00 & 1.72 & 2.03 & 1.6 & 11.78 & 45.01 & 37.35 & 67.73 & & 14.09 & 84.86 & 8.61 \\
\hline & & & 10.85 & 0.08 & 2.64 & 45.75 & & & & & 43.04 & 30.41 & 74.13 & & 12.57 & & 7.48 \\
\hline \multirow{2}{*}{ S18 } & & & & 0.10 & 2.89 & 42 & & & & & & 40.02 & & & & & 8.37 \\
\hline & & & 9.90 & 0.09 & 2.65 & 41.53 & & & & 12.26 & 42.85 & 35.85 & 70.02 & 210.53 & 15.28 & 82.39 & 7.43 \\
\hline \multirow{2}{*}{ S5 } & $0-17$ & 18.62 & 9.98 & 0.07 & 2.43 & 37.38 & 1.55 & 2.44 & 1.86 & 9.33 & 45.26 & 38.48 & 71.63 & 144.17 & 14.09 & 76.97 & 8.74 \\
\hline & $17-34$ & 21.27 & 8.31 & 0.06 & 2.29 & 30.98 & 1.33 & 2.33 & 2.15 & 7.85 & 37.10 & 27.37 & 64.21 & 172.44 & 13.33 & 76.44 & 7.23 \\
\hline
\end{tabular}

TABLE 5: Main biogeochemical indicators of the upper horizons of soils atop the division walls (R2, R5) and inside the fields of land plot S11-029 (S2, S5, S18).

\begin{tabular}{lccccc}
\hline \multirow{2}{*}{ Biogeochemical indicators } & $\mathrm{R} 2$ & $\mathrm{R} 5$ & $\mathrm{~S} 2$ & $\mathrm{~S} 18$ & $\mathrm{~S} 5$ \\
& $0-20.5$ & $0-13$ & $0-17$ & $0-15$ & $0-17$ \\
\hline$K_{\mathrm{e}}$ & 3.06 & 6.29 & 2.38 & 2.55 & 1.52 \\
$(\mathrm{Ca}+\mathrm{Mg}) / \mathrm{Al}$ & 0.41 & 0.17 & 0.53 & 0.49 & 0.78 \\
$\left(\mathrm{CaO}+\mathrm{MgO}+10 \cdot \mathrm{P}_{2} \mathrm{O}_{5}\right) / \mathrm{SiO}_{2}$ & 0.30 & 0.13 & 0.38 & 0.35 & 0.61 \\
$\beta$ & 0.68 & 0.66 & 0.78 & 0.80 & 0.88 \\
$K_{\mathrm{m}}$ & 2.27 & 2.14 & 1.84 & 1.84 & 2.07 \\
$K_{\mathrm{s}}$ & 1.11 & 1.18 & 1.00 & 1.01 & 0.91 \\
$\mathrm{SQ}$ & 0.48 & 0.42 & 0.48 & 0.47 & 0.48 \\
\hline
\end{tabular}

that the fallow land soils have losses of some trace elements. This is due to biological removal by crops and best seen in decreased concentrations of $\mathrm{Co}, \mathrm{Pb}, \mathrm{Zn}, \mathrm{Mn}$, and $\mathrm{Cu}$ (in descending order). In terms of an integral quality assessment (SQ), fallow soils and soils of the walls are similar. The A horizons of the postantique fallow land (S2, S18), and especially of fallow lands that had been cultivated both in antiquity and in modern times (S5), are characterized by lower values of the elution coefficient than the soil of the walls (1.9-3 times lower). This reflects more active leaching of calcium carbonate and salts (in relation to geochemically stable silica) as an effect of soil cultivation. The same is also suggested by the values of the leaching coefficient $(\beta)$ [80], which characterizes the losses of $\mathrm{Na}$ and $\mathrm{K}$ oxides in relation to alumina. Judging by the coefficient $\beta$ values, the relative difference in the degree of agrogenic transformation between the soils of the fields and that of the walls can be estimated at $18 \%$. The $K_{\mathrm{m}}$ parameter, which differs from $K_{\mathrm{e}}$ in the composition of labile elements, shows that, due to cultivation, the postantique fallow land still has a $17 \%$ higher degree of leaching in the upper soil horizon.

The water erosion in the period of agricultural activity at field S2 (F2) accounts for the following properties of its soil: an increased amount of carbonates in layer $0-17 \mathrm{~cm}$ as compared to layer $17-21 \mathrm{~cm}$ (by $7.7 \%$ ), a higher content of silica and particles of size $>0.01 \mathrm{~mm}$ (by 14\%) and, accordingly, a lower content of particles of size $<0.005 \mathrm{~mm}$ (by $11 \%)$. Changes in the particle size distribution are reflected in the aggregate composition of soils and in their erosion resistance [84].

As compared to the soil of wall R2 (at a depth of $20-51 \mathrm{~cm})$, soil of horizon A $(0-17 \mathrm{~cm})$ of field S2 (F2) is significantly inferior with regard to the total content of nine chemical elements used to calculate the $K_{\mathrm{s}}$ coefficient, especially in $\mathrm{Mn}, \mathrm{Cr}, \mathrm{Pb}$, and $\mathrm{Co}$ (ranked sequence). This can be explained by selective biological removal and partly by the eluviation process. By the sum of elements $\mathrm{Si}, \mathrm{Ca}, \mathrm{Al}, \mathrm{Fe}, \mathrm{Mn}$, $\mathrm{P}$, and $\mathrm{K}$, the postagrogenic horizon of the old arable soil is inferior to that of the virgin soil of the time of the land division by $16 \%$.

3.4. Biomorphic Analysis of Soils and Conditions of Land Use at the Turn of the $4^{\text {th }}$ and the $3^{\text {rd }}$ centuries BC. The soil of field S2 (F2) is characterized by a rather even distribution of almost all groups of biomorphs along the profile (from 0 to $34 \mathrm{~cm}$ ) (Table 6). This is not typical of virgin soils which have a clear peak of biomorphs in their uppermost horizon with a significant decrease down the profile. This is particularly true for phytoliths, cuticular imprints, and pollen. Except for the buried soils, the last two types of biomorphs should not be deep from the surface.

The long-term ploughing results in a tillage pan, i.e., a layer of compacted soil that accumulates dust particles that can migrate down the profile when being turbated. This layer is characterized by accumulation of phytoliths, which are carried by water through the soil pores. In this case (Table 6), a slight increase in phytoliths in 6-9 cm and $12-17 \mathrm{~cm}$ layers has been observed. Notably, all phytoliths in profile S2 (F2) were corroded, which indicates their ancient origin. It is 
TABLE 6: Silica microbiomorphs (unit \%) and distribution of phytolith forms (\%).

\begin{tabular}{|c|c|c|c|c|c|c|c|c|c|c|c|c|c|c|c|c|}
\hline \multirow{2}{*}{ Sample } & \multirow{2}{*}{ Depth $(\mathrm{cm})$} & \multirow{2}{*}{ Total } & \multirow{2}{*}{ Diatoms/spicules } & \multirow{2}{*}{ Total phytolith } & \multicolumn{12}{|c|}{ Phytolith distribution } \\
\hline & & & & & 1 & 2 & 3 & 4 & 5 & 6 & 7 & 8 & 9 & 10 & 11 & 12 \\
\hline \multirow{9}{*}{ S2 (F2) } & $0-3$ & $9 / 100$ & - & $9 / 100$ & 56 & - & - & 22 & 22 & - & - & - & - & - & - & - \\
\hline & $3-6$ & $18 / 100$ & $1 / 5 / / 1 / 5$ & $16 / 90$ & 19 & - & - & 12 & 25 & - & - & - & 19 & 13 & 12 & - \\
\hline & $6-9$ & $37 / 100$ & - & $37 / 100$ & 27 & 11 & - & 8 & 16 & - & - & - & - & 19 & 19 & - \\
\hline & $9-12$ & $28 / 100$ & $1 / 4 / /-$ & $27 / 96$ & 49 & 4 & - & 15 & 7 & - & 7 & 4 & - & 7 & 7 & - \\
\hline & $12-17$ & $33 / 100$ & - & $33 / 100$ & 34 & - & - & 3 & 6 & - & - & 21 & - & 21 & 15 & - \\
\hline & $17-21$ & $24 / 100$ & - & $24 / 100$ & 42 & 4 & - & 4 & 21 & - & - & 4 & - & 21 & 4 & - \\
\hline & $21-26$ & $2 / 100$ & - & $2 / 100$ & - & - & - & 50 & 50 & - & - & - & - & - & - & - \\
\hline & $26-31$ & - & - & - & - & - & - & - & - & - & - & - & - & - & - & - \\
\hline & $31-34$ & $1 / 100$ & - & $1 / 100$ & - & - & - & - & 100 & - & - & - & - & - & - & - \\
\hline \multirow{6}{*}{ R2 (F3) } & $0-3$ & $30 / 100$ & $3 / 10 / /-$ & $27 / 90$ & 33 & 15 & 7 & 7 & 19 & 4 & 15 & - & - & - & - & - \\
\hline & $3-6$ & $33 / 100$ & $-/ / 1 / 3$ & $32 / 97$ & 28 & 3 & - & 22 & 22 & 6 & - & - & - & 10 & 3 & - \\
\hline & $6-11$ & $26 / 100$ & - & $26 / 100$ & 22 & - & - & 8 & 50 & 4 & 1 & - & - & 15 & - & - \\
\hline & $11-16$ & $33 / 100$ & $1 / 3 / /-$ & $32 / 97$ & 31 & 6 & 3 & - & 10 & - & - & - & - & 29 & - & - \\
\hline & $16-21$ & $48 / 100$ & - & $48 / 100$ & 32 & 2 & 8 & 2 & 25 & - & - & - & - & 31 & - & - \\
\hline & $21-26$ & $44 / 100$ & - & $44 / 100$ & 25 & - & 7 & 16 & 20 & - & - & 9 & - & 23 & - & - \\
\hline $\mathrm{F} 4$ & $0-3$ & $36 / 100$ & - & $36 / 100$ & 58 & - & 8 & 11 & 15 & - & - & - & - & 8 & - & - \\
\hline F5 & $0-3$ & $5 / 100$ & - & $5 / 100$ & 80 & - & - & - & 20 & - & - & - & - & - & - & - \\
\hline F6 & $0-3$ & $9 / 100$ & - & $9 / 100$ & 44 & - & - & - & 22 & - & - & - & - & 34 & - & - \\
\hline F7 & $0-3$ & $15 / 100$ & - & $15 / 100$ & 47 & - & - & - & 20 & - & - & - & - & 13 & 13 & 7 \\
\hline F8 & $0-18$ & $5 / 100$ & - & $5 / 100$ & 60 & - & 20 & - & - & - & - & - & - & - & 20 & - \\
\hline
\end{tabular}

1: herbs; 2 : indicator types of coniferous species; 3 : trichomes of grasses of forest habitats; 4: trichomes of grasses of meadow-type habitats; 5 : short sells of grasses of steppe-type habitats; 6: dendritic firms, indicator of cereals; 7: reed; 8: indicator forms of grasses of arid-type habitats; 9: trichomes of grasses of ruderal habitats; 10: indicator forms of Artemisia; 11: mosses; 12: unknown and fragmented particles.

assumed that the field was ploughed at different times and at different depths, which created several tillage pans. On the northern Black Sea coast of classical times, the land was ploughed with a bow ard driven by oxen [38]. Therefore, one-pass tillage affected the upper soil layer only. Even much later, in $18^{\text {th }}-19^{\text {th }}$-century Western and Eastern Europe, ploughing was shallow. In the Ukrainian steppes, the depth of the ploughing horizon was $16-18 \mathrm{~cm}$ even in 1935-1940. It is noteworthy that, in the entire fallow soil profile, only a $12-17 \mathrm{~cm}$ layer contained a significant amount of arid-flora phytoliths. It is also this layer that, along with the underlying layer $(17-21 \mathrm{~cm})$, has the highest content of Artemisia phytoliths (21\%). As phytoliths are only sporadically found deeper than $21 \mathrm{~cm}$ (Table 7), the field was apparently ploughed maximum to this depth. However, the sediments could add additional $3-6 \mathrm{~cm}$ to the total thickness of the current soil profile. The distribution of biomorphs along the profile (Table 6) shows that tillage involved the upper $15 \mathrm{~cm}$ of soil. The depths that in the postantique fallow profile characterize the overturned top soil do possibly correspond to the two layers in the biomorphs' distribution: from 3 to $9 \mathrm{~cm}$ and from 12 to $21 \mathrm{~cm}$. Judging by the types of biomorphs, they were formed in similar climatic conditions, but the biomorphs of the lower layers correspond to somewhat more arid conditions. This is indicated by the fact that both layers contain significant amounts of phytoliths of dicotyledonous grasses, meadow, and steppe grasses, as well as of mosses, with the $12-21 \mathrm{~cm}$ layer showing a greater share of Artemisia and the absence of weed species. The amount of phytoliths identified may also indicate that no fertilizers such as manure, ash, or lacustrine sediments usually used in the region, as, for example, on the lands near Kerkinitis, were added to the soil [38].

As somewhat unexpected for ancient postagrogenic landscapes, we note in our samples the presence of phytoliths of conifers. Of course, this does not indicate the growth of coniferous trees directly on the land plot, but the branches of such trees must have been brought from nearby locations for further use by ancient farmers. The phytoliths of conifers have been identified in the fallow soil at the depths of 6-9, 9-12, and $17-21 \mathrm{~cm}$ in layers clearly turbated by tillage, as well as in the soil of the division wall at the depths of $0-3,12-17,3-6$, and $17-21 \mathrm{~cm}$ (from 15 to $2 \%$ in descending order). In addition, small amounts (from 3 to $8 \%$ ) of phytoliths of grasses of forest habitats were found in the soil of the division wall at the depths of 12-26 and $0-3 \mathrm{~cm}$. At present, there are no coniferous forests on the Tarkhankut Peninsula, but the evidence available suggests their presence in the area in the earlier periods, down to the first century $\mathrm{AD}[26,63]$. The largest amount of phytoliths of conifers (18\%) was found in soil on ash in an archaeological context of the $10^{\text {th }}$ century BC nearby Chernomorskoe (Settlement S11-022). Hence, phytoliths of conifers found in the postantique agricultural landscape should be considered relict forms.

The creation of a division wall resulted in the inversion of the soil profile, as the upper soil layers used in the construction must have formed the wall's base. The analysis of biomorphs along the soil profile of R2 (F3) also suggests that division walls were not tilled but might have rather been used for stacking some covering material, such as branches of conifers, reed grass, straw, etc. During the period of farming in this area, the division walls could have been 
TABLE 7: Semiquantitative content of different types of microbiomorphs of the studied soils.

\begin{tabular}{|c|c|c|c|c|c|c|c|c|}
\hline \multirow{2}{*}{ No. } & \multirow{2}{*}{ Depth $(\mathrm{cm})$} & \multicolumn{3}{|c|}{ Nonsiliceous vegetable indicators } & \multicolumn{2}{|c|}{$\begin{array}{l}\text { Siliceous nonvegetable } \\
\text { indicators }\end{array}$} & \multicolumn{2}{|c|}{ Plant silica } \\
\hline & & Detritus* & $\begin{array}{l}\text { Amorphic organic } \\
\text { material }^{*}\end{array}$ & Pollen and spores ${ }^{*}$ & Diatoms* & $\begin{array}{l}\text { Sponge } \\
\text { spicules* }\end{array}$ & Cuticles* & Phytoliths* \\
\hline \multirow{9}{*}{$\mathrm{S} 2(\mathrm{~F} 2)$} & $0-3$ & +++ & +++ & +++ & - & - & + & + \\
\hline & $3-6$ & +++ & +++ & Single & Single & Single & + & + \\
\hline & $6-9$ & ++ & +++ & - & - & - & + & + \\
\hline & $9-12$ & +++ & +++ & + & Single & - & + & + \\
\hline & $12-17$ & ++ & ++ & + & - & - & - & + \\
\hline & $17-21$ & ++ & ++ & Single & - & - & - & + \\
\hline & $21-26$ & +++ & +++ & + & - & - & - & Single \\
\hline & $26-31$ & +++ & +++ & + & - & - & Single & - \\
\hline & $31-34$ & ++ & ++ & Single & - & - & - & Single \\
\hline \multirow{6}{*}{ R2 (F3) } & $0-3$ & +++ & +++ & Single & Single & - & ++ & + \\
\hline & $3-6$ & +++ & +++ & + & - & Single & + & + \\
\hline & $6-11$ & ++ & ++ & - & - & - & - & + \\
\hline & $11-16$ & +++ & +++ & Single & Single & - & - & + \\
\hline & $16-21$ & ++ & ++ & - & - & - & ++ & + \\
\hline & $21-26$ & +++ & +++ & - & - & - & + & + \\
\hline $\mathrm{F} 4$ & $0-3$ & +++ & +++ & ++ & - & - & +++ & + \\
\hline F5 & $0-3$ & +++ & +++ & Single & - & - & - & + \\
\hline F6 & $0-3$ & ++ & +++ & + & - & - & + & + \\
\hline F7 & $0-3$ & +++ & +++ & ++ & - & - & ++ & + \\
\hline F8 & $0-18$ & +++ & +++ & - & - & - & - & + \\
\hline
\end{tabular}

*Relative amounts of biomorphs: +++ (many): over 100 ex.; ++ (medium): 40-100 ex.; + (few): 5-40 ex.; single: 1-4 ex.; none: -.

occasionally renewed, as evidenced by a small number of cereal phytoliths (4-6\%) that entered the wall's uppermost layer $(0-11 \mathrm{~cm})$ with the soil taken from the adjacent fields. Alternatively, these phytoliths might have come from the straw stacked on the wall.

The conifer branches, stalks of reed grass, and wild hemp (Cannabis) (or small nettle (Urtica)) presumably used as covering material are likely to have come into the fields' soil through the cultivation. According to Strabo (7.3.18), local vines were covered with earth, which also was a typical practice in the region in the late $19^{\text {th }}$ century. The straw of cereals apparently has not been used for this purpose, as their phytoliths were found only in sample R2 (F3) (4-6\% in 0-11 cm layer). Sample S2 (F2) revealed phytoliths of the common reed grass (Phragmites australis) $(7 \%$ in $9-12 \mathrm{~cm}$ soil layer). This fact needs to be considered together with the find of diatoms in the same soil layer. Diatoms were also attested in the 3-6 cm layer. Since phytoliths of the reed grass are not recorded in the layers above $9 \mathrm{~cm}$, it is safe to say that they came to the layer of $9-12 \mathrm{~cm}$ as a result of cultivation. This assumption is also supported by the fact that in the soil sample from the wall, they are recorded only in the uppermost layer of $0-3 \mathrm{~cm} \mathrm{(15 \% ).} \mathrm{At} \mathrm{present,} \mathrm{reed}$ grass, club-rush, and sea clubroot (Schoenoplectus lacustris and Scirpus maritimus) can still be found in the area in the lower reaches of large gullies emptying into salt lakes [85].

In antiquity, as at present, north-western Crimea was more arid than other parts of the peninsula [80]. Theoretically, diatoms and sponge spicules can be related to watering of fields. However, taking into account the absence of fresh water sources and specific terrain with the shallow carbonate soils, it seems unlikely that the land in question could have been irrigated. This is clearly indicated by the soil profile of the division wall that shows the presence of diatoms in the layer of $0-3 \mathrm{~cm}$ and sponge spicules in the layer of $3-6 \mathrm{~cm}$. At the same time, the finds of well-preserved diatoms and sponge spicules are attested in the fallow soil at the depths of $3-6 \mathrm{~cm}$ and $9-12 \mathrm{~cm}$. The fact that the same layer of 9-12 cm has also produced phytoliths of reed grass makes it likely that both types of biomorphs entered the soil together with lacustrine sediments. The nearest location where reed grass can still be found in natural conditions is Lake Liman (Karadzha) $\left(1.36 \mathrm{~km}^{2}\right)$ situated just $3 \mathrm{~km}$ away from the site.

The fact that profile S2 (F2) from land plot S11-029 yielded no cereal phytoliths suggests the production of crops other than grain, such as viticulture or legumes. Leguminous crops commonly planted between vine rows include lentils and bitter vetch (Vicia ervilia (L.) Willd.) that are usually used as fodder or green fertilizer and attested in archaeological record from the area ([65], p. 308).

The maximum amount of pollen and spores in the postantique fallow soil has been recorded in the uppermost layer of $0-3 \mathrm{~cm}$. Their fairly even distribution also in the layers below $3 \mathrm{~cm}$ points to ploughing activity. The same is also suggested by the finds of root remains and cuticular imprints of plants at the depth of $0-12 \mathrm{~cm}$, which would be unusual for an undisturbed soil profile. In explaining these finds, one also cannot rule out the possible effects of synlithogenetic pedogenesis that involved a periodic deposition of fine-grained sediments on the soil surface. The deposition of sediments in the ploughed soil is confirmed by its granulometry. The postagrogenic horizon of the fallow soil $(0-17 \mathrm{~cm})$ differs from the lower part of horizon A 
$(17-21 \mathrm{~cm})$ by a lower density of soil solid phase (2.35 vs $2.43 \mathrm{~g} \cdot \mathrm{cm}^{3}$ ), an increased content of clay (by $2.8 \%$; particle size $<0.001 \mathrm{~mm})$, and silt/sand $(>0.01 \mathrm{~mm})$ (by $13.8 \%)$, which points to the material being brought by rainfall runoff. The soil-erosion vulnerable conditions of the terrain are discussed in Section 3.1.

The top soil of wall R2 (F3) contains 5-50 grains of pollen and spores only in the $3-6 \mathrm{~cm}$ layer and sporadically in the $0-3 \mathrm{~cm}$ and $11-16 \mathrm{~cm}$ layers. In the latter case, it is the pollen of the ancient buried topsoil. The amount of cuticular imprints in the layers of $0-3 \mathrm{~cm}$ and $3-6 \mathrm{~cm}$ is estimated as medium and small, respectively. The same pattern is also characteristic of layers of $16-21$ and $21-26 \mathrm{~cm}$. The presence of buried top surface is indicated by the distribution of cuticular imprints and pollen along the wall's profile: along with the $0-6 \mathrm{~cm}$ layer of sod, they are recorded at the depth of $16-21 \mathrm{~cm}$, with a layer of sterile soil in between. Given that the reconstructed height of division walls amounted to $c$. $20 \mathrm{~cm}$, the depth of $16-21 \mathrm{~cm}$ must correspond to the buried topsoil.

The finds of microbial communities and of soil-mesofauna eggs, as well as of coprolites and hyphae, in the soil of postantique fallow land testify to its higher biological activity, as compared to the soil of the walls (Table 7).

The topsoil $(0-3 \mathrm{~cm})$ of virgin land (Table 7, F5) and that of old fallow (S2) are fairly similar in terms of biomorph content, except for pollen and spores, the quantity of which in the virgin soil is lower. This is explained by the conditions of the virgin soil sampling site (F5) which is located $600 \mathrm{~m}$ from the Black Sea shore with an active wind regime (with an average annual wind speed of $5.4 \mathrm{~m} \mathrm{~s}^{-1}$ and the number of days with the wind speed of $15+\mathrm{m} \cdot \mathrm{s}^{-1}$ amounting to 39). Notably, cuticular imprints, which are good markers of fallowing and of the relatively large fragments of fresh plants' having entered the soil, were found only in the long-fallow soil, both in the topsoil $(0-3 \mathrm{~cm})$ and below, to the depth of $12 \mathrm{~cm}$. While the amount of steppe grass phytoliths in these soils is fairly similar, the long-fallow soil shows the presence of meadow grass phytoliths and lower quantities of dicotyledonous herbs (on 24\%). Division walls regulated surface runoff, creating more favourable conditions for moisture storage within the land plot parcels, which, in turn, could lead to the formation of meadow-like vegetation in the fallow areas.

The presence of forest grass phytoliths in the contemporary dry steppe conditions can only be explained by their relict origin - a reflection of more humid climate in the past, which is also confirmed by the palaeogeographic data of the $4^{\text {th }}$ through the $2^{\text {nd }} / 1^{\text {st }}$ century BC [69]. In the division wall profile, this type of phytoliths is present in the topsoil $(0-3 \mathrm{~cm})$ and at a depth of $16-26 \mathrm{~cm}$, as well as, in smaller quantities, in the layer of $11-16 \mathrm{~cm}$. In addition, the forest flora is also attested in a turbated layer at site F4, its largest amounts being recorded in the $280-270 \mathrm{BC}$ context at the rural settlement of Kelsheikh 1 (F8).

An interesting distribution is observed in sample F4 (an abandoned garden with thick grass cover). It yielded more phytoliths than any other soil sample from current agricultural lands and contained heavily corroded phytoliths of forest herbs ( $8 \%$ ) which must be much older than the others. This is likely an effect of deep ploughing and soil transfer from the lower horizons.

The topsoil $(0-3 \mathrm{~cm})$ of the winter-wheat sown field (F7) revealed large fragments of cuticular imprints and fairly large charred particles of detritus, possibly due to the burning of stubble. The phytolith composition of this sample is close to that of an abandoned vineyard (F6), which differs only by a bigger (2.6 times) share of Artemisia. A comparable amount of Artemisia was observed in the soils of the postantique fallow land $(12-21 \mathrm{~cm}$ layer) and the division wall (11-26 cm layer). As shown above, an important point in the change of regional climate coincided with the intensification of agricultural activities in this area in the third quarter of the $4^{\text {th }}$ century BC or at the turn of the $4^{\text {th }}$ and $3^{\text {rd }}$ centuries.

Hence, the biomorphic analysis as part of geoarchaeological studies of ancient agrolandscapes has significant potential for the reconstruction of palaeogeographic conditions and ancient agricultural techniques.

\section{Conclusion}

Due to their scarcity and fragmentary character, literary sources are of little help in studying ancient land management and agricultural technology evolution in the Black Sea region. However, the use of geoarchaeological and pedoarchaeological methods gives a valuable insight into the agricultural practices of the ancients in the context of changing climatic conditions. In the northern Black Sea region, the array of geoarchaeological techniques used to study ancient systems of land division and management that were detected on aerial and satellite imagery and verified in the terrain depended on the complexity of research objectives. This study demonstrates the informative capabilities of this approach that integrates GIS, satellite-navigation and space technologies, in-field studies of microrelief and soil registrograms, and physicochemical, geochemical, and microbiomorphic soil analyses. We agree with the authors [86] who identify a phytolith profile as a special type, which as other profiles (humus, carbonate, texture, etc.) develops during the entire soil life span, recording in its qualitative and quantitative characteristics changes in the environment, soil-forming factors, or anthropogenic impacts. Further studies of postantique agrolandscapes in the northern Black Sea region can move in the direction of GIS-mapping of agrolandscape conditions other than those of "long fields," i.e., land division systems of orthogonal and irregular plan. This will help identify the common and specific traits in ancient farmers' approaches to the creation of agricultural infrastructure. For the pedogenesis model "soil on soil" (postagrogenic lands, land division walls, tumuli, etc.), there is also a need of developing a special chronofunction of changes in the thickness of $\mathrm{A}+\mathrm{AB}$ horizons depending on time. The preservation of ancient postagrogenic landscapes, including their soils and vegetation cover, for future generation of scholars is an important task, also in view of new emerging techniques in soil genetic research. This involves the need for the inscription of the most representative 
postantique agrolandscapes in the national or regional lists of specially protected historical and landscape areas. At present, despite the growing risk of the secondary steppes' being ploughed over, there are no territories in Crimea that have such a status. The long-fallow soils should be inscribed in the "Red book of soils", as containing valuable information on the soil system's agrogenic transformation and its subsequent renaturation.

\section{Data Availability}

Our primary data are presented in tables that accompany the text of the article. This dataset is the result of field and laboratory studies. It has not previously been published and can be used to verify the conclusions presented in this paper.

\section{Conflicts of Interest}

The authors declare no conflicts of interest with regard to the publication of this paper.

\section{Acknowledgments}

The reported research was funded by the Russian Foundation for Basic Research (grant no. 18-00-00562). Phytolith analyses were supported by the Institute of Geography, Russian Academy of Sciences, State Program (no. 0148-2019-0006).

\section{References}

[1] S. Limbrey, Soil Science and Archaeology, Academic Press, London, UK, 1975.

[2] Welsh Soils Discussion Group, Soils and Archaeology, Welsh Soils Discussion Group, London, UK, 1978.

[3] C. Cordova, Geoarchaeology: The Human-Environmental Approach, I. B. Tauris, London, UK, 2018.

[4] V. A. Demkin, V. M. Klepikov, S. N. Udaltsov, T. S. Demkina, M. V. Eltsov, and T. E. Khomutova, "New aspects of natural science studies of archaeological burial monuments (kurgans) in the southern Russian steppes," Journal of Archaeological Science, vol. 42, pp. 241-249, 2014.

[5] B. A. Maher, A. Alekseev, and T. Alekseeva, "Magnetic mineralogy of soils across the Russian steppe: climatic dependence of pedogenic magnetite formation "," Paleogeography, Paleoclimatology, Paleoecology, vol. 201, pp. 321-341, 2003.

[6] T. Alekseeva, A. Alekseev, B. A. Maher, and V. Demkin, "Late Holocene climate reconstructions for the Russian steppe, based on mineralogical and magnetic properties of buried palaeosols," Palaeogeography, Palaeoclimatology, Palaeoecology, vol. 249, no. 1-2, pp. 103-127, 2007.

[7] P. V. Goleusov and F. N. Lisetskii, "Soil development in anthropogenically disturbed forest-steppe landscapes," Eurasian Soil Science, vol. 41, no. 13, pp. 1480-1486, 2008.

[8] J. A. Sandor, "Ancient agricultural terraces and soils," in Footprints in the Soil: People and Ideas in Soil History, B. Warkentin, Ed., pp. 505-534, Elsevier, Amsterdam, Netherlands, 2006.

[9] T. N. Smekalova, B. W. Bevan, A. V. Chudin, and A. S. Garipov, "The discovery of an ancient Greek vineyard," Archaeological Prospection, vol. 23, no. 1, pp. 15-26, 2016.

[10] F. N. Lisetskii, Ed., Crimea: The History of Interaction between Man and Nature, Nova Science Publishers, New York, NY, USA, 2019.
[11] Y. Chendev, A. Petin, and A. Lupo, "Soils as indicators of climatic changes," Geography, Environment, Sustainability, vol. 5, no. 1, pp. 4-17, 2012.

[12] M. J. Kooistra and L. I. Kooistra, "Integrated research in archaeology using soil micromorphology and palynology," Catena, vol. 54, no. 3, pp. 603-617, 2003.

[13] O. E. Marfenina, A. E. Ivanova, E. E. Kislova, E. P. Zazovskaya, and I. Y. Chernov, "Fungal communities in the soils of early medieval settlements in the taiga zone," Eurasian Soil Science, vol. 41, no. 7, pp. 749-758, 2008.

[14] Y. G. Chendev, "Soils in the area of the antique town of Kitei (the Crimean Peninsula)," Eurasian Soil Science, vol. 38, pp. 834-842, 2005.

[15] Y. G. Chendev and A. V. Kulikov, "Man-caused modifications of soils in the vicinity of classical Kitheion," Russian Archaeology, vol. 3, pp. 44-54, 2004.

[16] F. N. Lisetskii and M. E. Rodionova, "Transformation of drysteppe soils under long-term agrogenic impacts in the area of ancient Olbia," Eurasian Soil Science, vol. 48, no. 4, pp. 347-358, 2015.

[17] A. V. Borisov, D. S. Korobov, I. A. Idrisov, and P. I. Kalinin, "Soils of agricultural terraces with retaining walls in the mountains of Dagestan," Eurasian Soil Science, vol. 51, no. 1, pp. 22-31, 2018.

[18] A. Borisov and I. Idrisov, "Effect of ancient terracing on soil balance in mounting zone of Dagestan (eastern Caucasus, Russia)," International Multidisciplinary Scientific GeoConference Surveying Geology and Mining Ecology Management, SGEM, vol. 18, pp. 135-142, 2018.

[19] E. Chernysheva, T. Khomutova, F. Fornasier, T. Kuznetsova, and A. Borisov, "Effects of long-term medieval agriculture on soil properties: a case study from the Kislovodsk basin, Northern Caucasus, Russia," Journal of Mountain Science, vol. 15, no. 6, pp. 1171-1185, 2018.

[20] F. N. Lisetskii, V. F. Stolba, and V. I. Pichura, "Late-Holocene palaeoenvironments of Southern Crimea: soils, soil-climate relationship and human impact," The Holocene, vol. 27, no. 12, pp. 1859-1875, 2017.

[21] A. Golyeva and N. Svirida, "Quantitative distribution of phytoliths as reliable diagnostical criteria of ancient arable lands," Quaternary International, vol. 434, pp. 51-57, 2017.

[22] P. R. Sola, "Sobre un tratado de agrimensura del siglo I (parte I)," Topografía y Cartografía, vol. 3, pp. 9-26, 1991.

[23] B. Campbell, The Writings Of the Roman Land Surveyors (Journal of Roman Studies Monograph 9), Society for the Promotion of Roman Studies, London, UK, 2000.

[24] M. De Nardis, "The writings of the Roman land surveyors: technical and legal aspects," Ph.D. Thesis, University College London, London, UK, 1994.

[25] J. Plue, S. Meuris, K. Verheyen, and M. Hermy, "The importance of artefacts of ancient land use on plant communities in Meerdaal forest," Belgian Journal of Botany, vol. 142, pp. 3-18, 2009.

[26] A. Chtcheglov, Polis et chora: cite et territoire dans le PontEuxin, CH Beck, Paris, France, 1992.

[27] G. M. Nikolaenko, "The chora of Tauric Chersonesos and the cadastre of the 4th-2nd century BC," in Surveying the Greek Chora: The Black Sea Region in a Comparative Perspective, B. G. Bilde and V. F. Stolba, Eds., pp. 151-174, Aarhus University Press, Aarhus, Denmark, 2006.

[28] C. E. Cordova and P. H. Lehman, "Mediterranean agriculture in south-western Crimea: palaeo-environments and early adaptations," in Beyond the Steppe and Sown, the Proceedings of the 2002 University of Chicago Conference on Eurasian 
Archaeology (Colloquia Pontica 13), D. L. Peterson, L. M. Popova, and A. T. Smith, Eds., pp. 425-447, Brill, Leiden, Netherlands, 2002.

[29] J. C. Carter, M. Crawford, P. Lehman, G. Nikolaenko, and J. Trelogan, "The chora of Chersonesos in Crimea, Ukraine," American Journal of Archaeology, vol. 104, no. 4, pp. 707-741, 2000.

[30] C. Cordova, Crimea and the Black Sea: An Environmental History, Bloomsbury Publishing, London, UK, 2016.

[31] F. Lisetskii, V. Stolba, E. Ergina, M. Rodionova, and E. Terekhin, "Post-agrogenic evolution of soils in ancient Greek land use areas in the Herakleian Peninsula, southwestern Crimea," The Holocene, vol. 23, no. 4, pp. 504-514, 2013.

[32] S. J. Saprykin, Ancient Farms and Land Plots on the Khora of Khersonesos Taurike, Brill, Amsterdam, Netherlands, 1994.

[33] F. Lisetskii, E. Zelenskaya, and M. Rodionova, "Geochemical features of fallow land in ancient plots in the chora of Chersonesos," Geosciences, vol. 8, no. 11, p. 410, 2018.

[34] T. Smekalova and E. Terekhin, "New evidences about socialmilitary organization of Tauric Chersonesos as reflected in the structure of its cadaster," Stratum Plus: Archaeology and Cultural Anthropology, vol. 6, pp. 89-105, 2018.

[35] A. N. Ščeglov, "Utilisation de la photographie aérienne dans l'étude du cadastre de Chersonésos Taurique (IVe-IIe s. av. n. ère)," Dialogues d'histoire ancienne, vol. 6, no. 1, pp. 59-72, 1980 .

[36] A. V. Karjaka, "The demarcation system of the agricultural environment of Olbia Pontike," in Meetings of Cultures in the Black Sea Region: Between Conflict and Coexistence, P. G. Bilde and J. H. Petersen, Eds., pp. 181-192, University Press, Aarhus, Denmark, 2008.

[37] P. G. Bilde and V. F. Stolba, Surveying the Greek Chora. Black Sea Region in a Comparative Perspective, University Press, Aarhus, Denmark, 2006.

[38] V. A. Kutaysov, The Antique Polis of Kerkinitis, Predpriyatie Fenix, Simferopol, Ukraine, 2013.

[39] V. G. Zubarev and S. L. Smekalov, "Map of archaeological sites tracts Adzhiel in the eastern Crimea, according to different sources," Modern Applied Science, vol. 9, no. 3, pp. 184-191, 2014.

[40] V. Zubarev, S. Smekalov, and S. Yartsev, "Materials for the ancient landscape reconstruction in the Adzhiel landscape compartment in the eastern Crimea (the first stage research results)," Journal of Archaeological Science: Reports, vol. 23, pp. 993-1013, 2019.

[41] N. V. Bykovskaya and T. N. Smekalova, "Traces of orthogonal land division in the eastern and northwestern Crimea: ancient times or the 19th century?" Journal of Historical, Philological and Cultural Studies, vol. 1, no. 63, pp. 126-139, 2019.

[42] H. Lin, "Three principles of soil change and pedogenesis in time and space," Soil Science Society of America Journal, vol. 75, no. 6, pp. 2049-2070, 2011.

[43] V. O. Targulian and M. A. Bronnikova, "Soil memory: theoretical basics of the concept, its current state, and prospects for development," Eurasian Soil Science, vol. 52, no. 3, pp. 229-243, 2019.

[44] F. N. Lisetskii, "Agrogenic transformation of soils in the dry steppe zone under the impact of antique and recent land management practices," Eurasian Soil Science, vol. 41, no. 8, pp. 805-817, 2008.

[45] V. O. Targulian and S. V. Goryachkin, "Soil memory: types of record, carriers, hierarchy and diversity," Revista Mexicana de Ciencias Geologicas, vol. 1, pp. 1-8, 2004.
[46] S. Kharal, B. Khanal, and D. Panday, "Assessment of soil fertility under different land-use systems in Dhading district of Nepal,” Soil Systems, vol. 2, no. 4, p. 57, 2018.

[47] J. A. Sandor and J. A. Homburg, "Anthropogenic soil change in ancient and traditional agricultural fields in arid to semiarid regions of the Americas," Journal of Ethnobiology, vol. 37, no. 2, pp. 196-217, 2017.

[48] A. Barczi, A. A. Golyeva, and Á. Peto, "Palaeoenvironmental reconstruction of Hungarian kurgans on the basis of the examination of palaeosoils and phytolith analysis," Quaternary International, vol. 193, no. 1-2, pp. 49-60, 2009.

[49] G. W. Dimbleby, The Palynology of Archaeological Sites, Academic Press, London, UK, 1985.

[50] I. Rovner, "Macro- and micro-ecological reconstruction using plant opal phytolith data from archaeological sediments," Geoarchaeology, vol. 3, no. 2, pp. 155-163, 1988.

[51] A. A. Gol'yeva, "Experience in using phytolith analysis in soil science," Eurasian Soil Science, vol. 28, pp. 248-256, 1996.

[52] A. A. Gol'eva and A. L. Aleksandrovskii, "The application of phytolith analysis for solving problems of soil genesis and evolution," Eurasian Soil Science, vol. 32, pp. 884-891, 1999.

[53] D. R. Piperno, Phytolyth Analysis: An Archaeological and Geological Perspective, Academic Press, Elsevier, New York, NY, USA, 2014.

[54] A. Golyeva and M. Andrič, "Palaeoecological reconstruction of wetlands and Eneolithic land use in Ljubljansko barje (Slovenia) based on biomorphic and pollen analysis," Catena, vol. 112, pp. 38-47, 2014.

[55] O. S. Khokhlova, N. L. Morgunova, A. A. Khokhlov, and A. A. Gol'eva, "Climate and vegetation changes over the past 7000 Years in the Cis-Ural steppe," Eurasian Soil Science, vol. 51, no. 5, pp. 506-517, 2018.

[56] A. Golyeva, O. Khokhlova, M. Lebedeva, N. Shcherbakov, and I. Shuteleva, "Micromorphological and chemical features of soils as evidence of Bronze Age ancient anthropogenic impact (late Bronze Age Muradymovo Settlement, Ural region, Russia)," Geosciences, vol. 8, no. 9, p. 313, 2018.

[57] Z. C. Dunseth, D. Fuks, D. Langgut et al., "Archaeobotanical proxies and archaeological interpretation: a comparative study of phytoliths, pollen and seeds in dung pellets and refuse deposits at early Islamic Shivta, Negev, Israel," Quaternary Science Reviews, vol. 211, pp. 166-185, 2019.

[58] S. Morell-Hart, "Techniques for integrating macrobotanical and microbotanical datasets: examples from pre-hispanic northwestern Honduras," Journal of Field Archaeology, vol. 44, no. 4, pp. 234-249, 2019.

[59] A. Rusakov, A. Makeev, O. Khokhlova et al., "Paleoenvironmental reconstruction based on soils buried under Scythian fortification in the southern forest-steppe area of the East European Plain," Quaternary International, vol. 502, pp. 197217, 2019.

[60] A. Smith, L. Proctor, T. C. Hart, and G. J. Stein, “The burning issue of dung in archaeobotanical samples: a case-study integrating macro-botanical remains, dung spherulites, and phytoliths to assess sample origin and fuel use at Tell Zeidan, Syria," Vegetation History and Archaeobotany, vol. 28, no. 3, pp. 229-246, 2019.

[61] X.-R. Zhang, Y. Du, C.-M. Ma, S.-F. Ping, C. Feng, and A.-N. Cui, "Climatic controls on peat swamp formation and evolution since 1300 year BP as recorded by phytoliths in the Xishan mountains, Jiangxi province, China," Palaeogeography, Palaeoclimatology, Palaeoecology, vol. 522, pp. 76-88, 2019.

[62] A. Golyeva, "Biomorphic analysis as a part of soil morphological investigations," Catena, vol. 43, no. 3, pp. 217-230, 2001. 
[63] V. F. Stolba, Greek Countryside in Ancient Crimea: Chersonesean Chora in the Late Classical to Early Hellenistic Period, Aarhus University, Aarhus, Denmark, 2014.

[64] A. N. Shcheglov, Severo-Zapadnyj Krym v antichnuyu epokhu, Nauka, Leningrad, Russia, 1978.

[65] V. F. Stolba, "The oath of Chersonesos and the Chersonesean economy in the early Hellenistic period," in Making, Moving and Managing. The New World of Ancient Economies, 323-31 $B C$, Z. H. Archibald, J. K. Davis, and V. Gabrielsen, Eds., pp. 298-321, Oxbow, Oxford, UK, 2005.

[66] A. N. Shcheglov, Polis i chora, Simferopol, Tavriya, Russia, 1976.

[67] I. V. Ivanov and F. N. Lisetskiy, "Correlation of soil formation rhythms with periodicity of solar activity over the last 5000 years. Transactions (doklady) of the Russian Academy of Sciences," Earth Science Sections, vol. 340, no. 1, pp. 189-194, 1996.

[68] R. P. C. Morgan, Soil Erosion, Longman, London, UK, 1979.

[69] N. I. Vinokurov, "Viticulture and wine production in the antique states of the northern Black Sea area," Bosporos Studies, vol. 3, pp. 22-39, 2007.

[70] S. A. Muld and T. N. Smekalova, Stone Kurgans on the Tarkhankut Peninsula, Dolja, Simferopol, Russia, 2012.

[71] F. N. Lisetskii, V. I. Chernyavskikh, and O. V. Degtyar, "Pastures in the zone of temperate climate: trends for development, dynamics, ecological fundamentals of rational use," in Pastures: Dynamics, Economics and Management, N. T. Procházka, Ed., pp. 51-84, Nova Science Publishers, Inc., New York, NY, USA, 2010.

[72] F. N. Lisetskii, Z. A. Buryak, and O. A. Marinina, "Soilgeomorphological characteristics of the infrastructure elements of the ancient economic activity in the Crimea," Computer programs, vol. 5, 2019.

[73] F. N. Lisetskii, V. F. Stolba, and P. V. Goleusov, "Modeling of the evolution of steppe chernozems and development of the method of pedogenetic chronology," Eurasian Soil Science, vol. 49 , no. 8 , pp. 846-858, 2016.

[74] E. V. Arinushkina, Manual for the Chemical Analysis of Soils, University Press, Moscow, Russia, 1970.

[75] A. Munsell, Munsell Soil Color Charts, Gretag Macbeth, New York, NY, USA, 1994.

[76] F. N. Lisetskii, T. N. Smekalova, and O. A. Marinina, "Biogeochemical features of fallow lands in the steppe zone," Contemporary Problems of Ecology, vol. 9, no. 3, pp. 366-375, 2016.

[77] G. Liu, L. Li, L. Wu, G. Wang, Z. Zhou, and S. Du, "Determination of soil loss tolerance of an entisol in southwest China," Soil Science Society of America Journal, vol. 73, no. 2, pp. 412-417, 2009.

[78] G. Taylor, C. F. Pain, and P. J. Ryan, "Geology, geomorphology and regolith," in Guidelines for Surveying Soil and Land Resources, N. J. McKenzie, M. J. Grundy, R. Webster, and A. J. Ringrose-Voase, Eds., pp. 45-60, Csiro, Melbourne, Australia, 2008.

[79] D. M. Shaw, Interprétation geochimique des éléments en traces dans les roches cristallines, Masson, Paris, France, 1964.

[80] H. Jenny, "Behavior of potassium and sodium during the process of soil formation," Missouri Agricultural Experiment Station Research Bulletin, vol. 162, pp. 42-52, 1931.

[81] F. N. Lisetskii, Zh. A. Buryak, and E. Zelenskaya, "The infrastructure of land management in the post-antique agrolandscapes of Crimea," Biogeosystem Technique, vol. 5, pp. 71-86, 2018.

[82] V. F. Stolba, "La vie rural en Crimée antique: Panskoe et ses environs," Études de Lettres, vol. 1-2, pp. 311-364, 2012.
[83] V. F. Stolba and J. Andresen, "Unveiling the hinterland: a new type of Hellenistic rural settlement in Crimea," Antiquity, vol. 89, no. 344, pp. 345-360, 2015.

[84] S. Y. Bulygin and F. N. Lisetskiy, "Soil microaggregation as an index of erosion resistance," Eurasian Soil Science, vol. 24, no. 3, pp. 59-65, 1992.

[85] P. D. Podgorodetsky, Northwest Crimea, USSR, Simferopol, Crimea, 1979.

[86] D. A. Gavrilov, S. V. Loiko, and N. V. Klimova, "Holocene soil evolution in South Siberia based on phytolith records and genetic soil analysis (Russia)," Geosciences, vol. 8, 402 pages, 2018. 